\title{
How Secure Was That Public Service Job? Redundancy in the Queensland Public Service \\ Linda Colley*
}

Public service employment has traditionally been perceived as secure and permanent. This security has been reduced in recent years, as economic pressures and broader public sector reforms have resulted in the redundancy of numerous public servants. While many consider this to be a revolutionary or novel trend, a review of the Queensland public service demonstrates that redundancies have long been a feature of public sector employment. The nature of redundancy appears to have changed over time, with earlier redundancies being largely related to economic circumstances, and those in more recent times being related less to economic cycles than to organisational decisions to restructure. The legislative provisions for redundancy have also changed and become more flexible and accessible. This combination of the change in the nature of redundancy, and the more accessible provisions, is not consistent with the traditional rationale for public service tenure as a protection against political dismissal.

While public service employment has traditionally been perceived as secure and permanent, this security has been reduced in recent years. Redundancy has been used to address economic and ideological pressures to 'downsize' public services and introduce private provision of services. Given the common perception of public service tenure, this reduction in public sector employment security might be considered novel or revolutionary.

This paper begins with a review of the rationale for public service employment security, which provided a stable and impartial workforce that was not subject to the whims of newly elected governments. The paper then considers recent industrial trends toward reduced employment security, and the increasing and changing nature of redundancy. The analysis continues through a case study of the Queensland public service.

The paper argues that, contrary to common perceptions of public service tenure, there has always been scope for redundancy in public service employment. The nature of redundancy appears to have changed over time. Earlier redundancies were largely related to economic circumstances, and undertaken with a view to relocating or re-employing retrenched workers as possible. More recent redundancies are both a reaction to economic cycles as well as a consequence of pro-active management choice during organisational restructuring. The legislative provisions for redundancy have also changed and become more flexible and accessible, with lesser regard for traditional notions of a career service. This combination of the changes in the nature of, and access to, redundancy is not consistent with the traditional rationale for tenure as a protection against political dismissal. While the paper focuses on redundancy developments, it provides a secondary stream of discussion on management's preparedness to make political decisions in recruitment through the use of temporary employment and special certificates of entry. Given this predisposition in recruitment decisions, it is possible that patronage and political considerations may have influenced dismissal decisions. 


\section{The Rationale for Public Service Tenure}

Prior to the 1850s, public services in Britain and Australia were plagued by problems of corruption and inefficiency. A 'spoils to the victor' system flourished, under which public service positions were the gift of a politician or department head. ${ }^{1}$ All civil service appointments were filled through political patronage, typically to meet some personal or political obligation, and usually with little consideration of the competence of appointees. There was little employment security, as each new government sought to employ its own supporters, often at the expense of existing employees. $^{2}$

A crisis in British administration led to the landmark Northcote-Trevelyan Report ${ }^{3}$ of 1853, which provided a blueprint for the transformation from a patronage system to a career service model. The Report noted that government:

could not be carried on without the aid of an efficient body of permanent officers ... possessing sufficient independence, character, ability, and experience to be able to advise, assist, and to some extent, influence, those who are from time to time set over them. [emphasis added $]^{4}$

Public services were reformed to foster a politically neutral career service in line with Westminster traditions. The major elements of the career service model included: standardised conditions of employment; administration by an independent agency; merit-based recruitment through competitive examination; merit-based promotion; a code of rights and protections; and adherence to the principles of a career service (such as employment security). These conventions became a model for public sector employment in Australia, implemented to varying degrees by the colonies/states from the 1850s and serving as a template for the new federal public service from 1901. The conventions were generally enshrined in public service legislation until the 1980s, although there are many examples where the legislative intentions were undermined by policy and practice and where implementation fell short of the ideal (such as seniority-based promotion). ${ }^{5}$

The recommendation that officers be permanent and independent recognised the political nature of the public service work environment, and marked a major difference to private sector employment relations. Tenure was not just a good employment practice, but also an important element of an integrated career service model, essential for effective policy development and service delivery in a political environment. Employment security enabled a professional and impartial public service to provide frank advice without fear of dismissal. A non-partisan public service was able to serve any government, and did not need to be dismissed upon a change of government. Significant appeal processes assisted to ensure that dismissal was only for purposes of misconduct or inefficiency, and not for political or other inappropriate grounds. Employment structures had to make it both difficult to enter the public service and difficult to remove employees. ${ }^{6}$ Within this employment framework, temporary employment could be an aberration for two reasons: first, it did not provide the security and independence necessary for frank and fearless advice; and second, temporary employment allowed patronage, as it was often not subject to the same stringent merit selection processes that applied to permanent employment. 
This traditional notion of tenure has made the recent spate of public service redundancies seem novel or revolutionary. Indeed, in the last two decades, employment security has declined in both the public and private sectors, rendering 'almost obsolete the conventional notion of a full-time, permanent job carried out for most of one's working life'. ${ }^{7}$ ACIRRT notes that, historically, employment insecurity was related to business cycles and the health of the economy, with downturns in business rippling through organisations. In the 1980s and 1990s, this pattern changed, and job insecurity 'became entwined with de-industrialisation and with organisational restructuring':

Many firms had taken the opportunity of a downturn to 'rationalise' their production process. In some cases, this meant new technology; in other cases it meant setting up production overseas. ... In the case of organisational restructuring, large numbers of jobs were lost purely through management decisions about the future shape of the organisations. The state of the business cycle had little to do with this process of organisational change, though managers often took advantage of business downturns to implement their strategies for change. ${ }^{8}$

The sacking of workers in these circumstances was referred to in sanitised terms as 'downsizing' and later 'right-sizing'. ${ }^{9}$ Littler et al agree that while downsizing is not a new phenomenon, its more recent manifestation does have several new aspects:

The targets of downsizing changed in the 1980s: from blue-collar workers in the 1960s and 1970s to white-collar workers and middle managers in recent years. Second, past lay-offs were reactive phenomena: a reaction to economic crisis was typically plant closures. Now, downsizing is disassociated from the business cycle and is just as likely to be a proactive phenomenon. Third, associated with the above, downsizing is seen to be a restructuring strategy with intent to achieve a new organizational structure or a new level of competitiveness. ${ }^{10}$

[These changes have been matched to some extent by industrial changes. The ILO Termination of Employment Convention ${ }^{11}$ provides basic standards in relation to termination of employment, requiring a valid reason for the dismissal, and the ability to challenge dismissal before an impartial body. The 1984 Termination, Change and Redundancy decision expanded the range of employer obligations related to dismissal, including consultation and notification requirements, and severance payments, although these protections have since been watered down. $]^{12}$

Littler suggests that by the 1990s, the public sector was a leader in downsizing. ${ }^{13}$ Changing ideologies and economic pressures led governments to question the public provision of services and the size of government, and in turn to alter traditional forms of public administration through means including privatisation, outsourcing, contracting and commercialisation. This reform and organisational restructuring has led to increased redundancies. As in the private sector, redundancies first occurred amongst blue-collar workers in public sector authorities and utilities, and then spread to white-collar workers and middle managers. ${ }^{14}$

Creighton and Stewart suggest that the reduction in safeguards against termination of public service employment is a recent phenomenon: 
As with other distinctive aspects of public sector regulation, the protections have in recent times been diminished or even abrogated by conservative governments intent on introducing private sector standards and practices in the public sector. ${ }^{15}$

McCarry challenges this notion of a decline in traditional public sector employment rights:

Retrenchments on the scale which has occurred could not have been imagined until about a decade ago. So the workers' security of employment, their tenure, seems to have declined. Yet in legal terms, tenure in the public sector has not died. In legal terms it never existed. In general, there has always been at least adequate and often ample power to terminate the services of public sector workers. In fact, in some services, the state of the law was such that employees had less legal security than workers in the private sector. ${ }^{16}$

The legislative changes have not been as radical as the number of retrenchments might suggest, although the existing provisions have been simplified and strengthened. Rather, the increase in redundancies may be the result of a preparedness to abandon previously unarticulated assumptions and expectations, and 'tear up ... the implicit contract'. ${ }^{17}$

\section{Case Study - Queensland Public Service}

This paper considers redundancy in a case study of the Queensland Public Service, from the establishment of the colony in 1859 until the reforms of the late 1980s and early 1990s. It draws primarily on public service legislation and annual reports.

Note that this analysis is restricted to the public service and not the broader public sector. While the composition changed throughout the period, the core departments generally included functions such as works, roads, finance, and employment, and the public service was much smaller than the broader public sector, which often included professional and technical groups such as railway employees, power workers and teachers.

\section{Civil Service Act 1863}

Redundancy provisions were available from the very beginning in the Queensland public service. In 1860, the first Governor of Queensland claimed to support the British public service conventions of merit and tenure. The Civil Service Act $1863^{18}$ aimed to establish 'an equitable and uniform system of appointment, promotion and dismissal'. It provided for redundancy and compensation where an office was abolished:

When the services of any officer are dispensed with in consequence of the abolition of the office he holds or otherwise and not through any fault of his own he shall as compensation receive for each year of service one month's salary according to the rate paid him at time of such abolition and a proportionate sum for any additional period less than a year. ${ }^{19}$ 
The new concept of tenure was soon under threat. The Government and the public service were under attack by the mid-1860s, due to public concerns about the effectiveness of the Act and mismanagement of promotions and pay increases. ${ }^{20}$ The general view was summed up by one Parliamentarian, who suggested that the public uneasiness 'might be traced to the operation of the Civil Service Act, which appeared almost to take the control of the officers out of the hands of the Government'. ${ }^{21}$ Some parliamentarians thought that tenure encouraged public servants to believe they could do anything they liked, and that the removal of tenure would solve all performance problems. Others reiterated the reasons for maintaining a permanent apolitical civil service, rather than the roundabout of the US system where old servants were turned out upon each change of government. They suggested that performance problems were not caused by the Act but, rather, by bad appointments and lack of supervision. ${ }^{22}$ The 1863 Act was a 'dead letter' by 1869 , as politicians continually by-passed its intentions, and maintained patronage, retrenchment, lateral recruitment and the use of temporary employees to bypass merit selection processes. ${ }^{23}$ It was repealed in $1869,{ }^{24}$ and public service recruitment and other employment conditions were unregulated for the next 20 years.

In summary, tenure failed to take root in this early period, as the desire to maintain patronage rights outweighed the desire to implement more independent recruitment and dismissal processes.

\section{Civil Service Act 1889/Public Service Act 1896}

The 1880s and 1890s saw the first industrial relations legislation and the formation of employer bodies and unions. Queensland followed the worldwide trends - unions became more militant, and by the mid-1880s, 'radical theories and doctrines were permeating the colony' preparing the way for an upsurge of organised labour. The Queensland Trades and Labour Council (TLC) was established in 1885, and the Trade Unions Act of 1886 allowed for the registration of trade unions. ${ }^{25}$ However, public servants were, with few exceptions, outside the union movement. Unions formed for some public sector workers such as those in the railways, but for most government employees, the removal of rights to promotion or the threat of dismissal (in the case of women workers) were effective deterrents to their union participation. ${ }^{26} \mathrm{~A}$ public service association was formed in 1890, but this was not a union or even a body officially recognised by governments; it was simply a voluntary body formed to promote the common interests of members. ${ }^{27}$

Public servants were worried about their lack of rights and tendencies toward patronage, and campaigned successfully for review and reform. ${ }^{28}$ An 1889 Royal Commission reported that the ad hoc system was ineffective, and recommended new legislation that implemented the career service conventions. ${ }^{29}$ The new Civil Service Act 1889 established a Civil Service Board to monitor merit and tenure, ${ }^{30}$ and the Public Service Act $1896^{31}$ largely repeated the 1889 Act provisions. The new legislation protected against any harsh or political decisions, but still provided for retrenchment:

no officer in the Service shall be dismissed therefrom or suffer any other penalty in respect thereof except in the manner set forth in this act; but nothing herein contained shall be taken to prevent the Governor in Council reducing the number of officers in any department, or dispensing with the services of any officers. ${ }^{32}$ 
It attempted to ameliorate this situation by providing for the re-employment of retrenched officers:

Any competent officer whose services may be dispensed with through no fault of his own, but in consequence of the reduction of the number of officers in any Department ... shall ... have a prior claim to re-appointment without examination when a vacancy occurs in any branch of the Service in the same class in which he was last employed. ${ }^{33}$

Tenure was compromised by the financial depression of the early 1890s, and the new Civil Service Board faced extensive public criticism. In its first year of operation, amidst criticism that it had made 'haphazard retrenchments', the Board noted the dilemma of balancing the need to reduce expenditure with its reluctance to discharge 'old and well-trained officers' during a depression, when alternative work was unlikely to be available. The Board considered that the Legislature anticipated gradual improvement of efficiency through administration of the new Act, and that natural attrition would achieve the required reductions in officers and salaries. ${ }^{34}$ Criticism of the Board escalated in 1893 as the depression worsened, and the Board struggled to highlight its efforts to assist in expenditure reduction through review of departmental budgets. ${ }^{35}$ Notwithstanding the public criticism, many officers were retrenched during this period. Table 1 demonstrates that 265 officers, or approximately 16 per cent of the workforce, were retrenched between 1890 and 1895, with peak retrenchments of 6.08 per cent in 1891 and 5.83 per cent 1893 . There were no unions able to protest against these redundancies, and the economic crisis may have rendered any industrial protest ineffective.

Table 1: Retrenchments from 1890-95

\begin{tabular}{|l|c|c|c|}
\hline Year & Retrenchments & $\begin{array}{c}\text { Total } \\
\text { Workforce }\end{array}$ & $\%$ \\
\hline $\mathbf{1 8 9 0}$ & 34 & 1759 & $1.93 \%$ \\
\hline $\mathbf{1 8 9 1}$ & 101 & 1660 & $6.08 \%$ \\
\hline $\mathbf{1 8 9 2}$ & 22 & 1634 & $1.35 \%$ \\
\hline $\mathbf{1 8 9 3}$ & 90 & 1544 & $5.83 \%$ \\
\hline $\mathbf{1 8 9 4}$ & 15 & 1555 & $0.96 \%$ \\
\hline $\mathbf{1 8 9 5}$ & 3 & 1582 & $0.19 \%$ \\
\hline Total & $\mathbf{2 6 5}$ & & $\mathbf{1 6 . 3 4 \%}$ \\
\hline
\end{tabular}

Source: Civil Service Board Annual Reports 1890-95

The Board made significant efforts to follow the re-employment provisions under the Act. ${ }^{37}$ A list of retrenched officers was maintained, and many were re-employed from 1890-92, with fewer re-employed in the worst stages of the depression from 1893-95..$^{38}$ In addition to retrenchments, the Special Retrenchment Act $1893^{39}$ reduced salaries by 10 per cent and was described as an 'unnecessarily harsh thing' ${ }^{40}$ The depression hit all colonies hard. Caiden has noted that, at first, governments made the public service a scapegoat, stopping projects, reducing salaries and removing conditions, but eventually they had to accept the necessary costs of administration 
and the advantages in efficiency and morale to be gained from orderly personnel practices. ${ }^{41}$ The lack of superannuation provisions meant that there were many older employees in the service who could not be retired without inflicting hardship. ${ }^{42}$

Patronage began to increase in this period. ${ }^{43}$ Premier Dickson considered that individuals who had supported his Government should have first call on any vacancies in the public service. ${ }^{44}$ The Board was unable to resist political interference and was over-ruled on salary and appointment matters. ${ }^{45}$ Both Acts allowed for temporary employment to be undertaken at department level without the usual stringent central merit selection processes, and without any guidance as to when it should be used. As such, it became one means to circumvent strict merit selection processes and dispense patronage. While no central statistics are available on these departmental decisions, the temporary employment option appears to have been abused. The alarming increase in temporary employment after $1896^{46}$ led the Board to issue cautions in 1899 and urge permanent appointments where possible. ${ }^{47}$ Patronage was also still possible due to the use of a loophole that allowed recruitment of people without examination subject to the issuing of a special certificate indicating that nobody within the service was suitable. The use of this loophole escalated from an average of two certificates per year from 1889-96 to an average of 25 per year from $1896-1900 .{ }^{48}$ It is unlikely that the Government's predisposition toward political patronage was limited only to recruitment. While it is not possible to identify the reasons behind each retrenchment decision, it is likely that at least some were used to make way for the friends of incoming ministers or governments.

\section{Public Service Act Amendment Acts of 1901 and 1920}

The 1901 Act abolished the existing bureaucrat-managed Public Service Board, and provided that its powers, authorities and duties should be undertaken by the Executive Council. ${ }^{49}$ The primary justification here was that half of the workforce was transferred to Commonwealth control following federation, ${ }^{50}$ and Ministers would thus have time to undertake these responsibilities for the remaining workforce. ${ }^{51} \mathrm{~A}$ further justification was that the existing Board was ineffective, being comprised of 'old civil servants saturated with traditions of the service', whose limited tenure made it difficult to resist political influence. ${ }^{52}$ This was the antithesis of the convention of independent management of the public service, and placed personnel decisions directly into the hands of politicians.

The retrenchment provisions from 1889 were continued in the Public Service Act Amendment Acts of 1901 and 1920.53 As in previous periods, tenure continued to be affected by economic downturns. The Special Retrenchment Act $1902^{54}$ led to further wage reductions and retrenchments. Table 2 indicates that 127 officers were retrenched between 1902-05, peaking at 7.3 per cent in 1902, and totalling more than 16 per cent of the workforce over a four-year period. It is of interest that, despite the retrenchment of more than 16 per cent of the workforce, there was only an overall net reduction of 3.6 per cent. While this might be explained in a number of ways, including a lack of service-wide planning and redeployment, it also raises questions regarding the genuine need to retrench these positions and officers. 
Table 2: Retrenchments from 1902-05

\begin{tabular}{|c|c|c|c|}
\hline Year & Retrenchments & $\begin{array}{c}\text { Total } \\
\text { Workforce }\end{array}$ & $\%$ \\
\hline 1902 & 58 & 794 & $7.3 \%$ \\
\hline 1903 & 33 & 788 & $4.19 \%$ \\
\hline 1904 & 33 & 765 & $4.31 \%$ \\
\hline 1905 & 3 & 785 & $0.38 \%$ \\
\hline \multicolumn{2}{|r}{} & $16.49 \%$ \\
\hline
\end{tabular}

Source: Public Service Board Annual Reports 1902-05 55

The Public Service Board expressed regret for having to take such severe measures and, where possible, re-appointed retrenched officers when suitable temporary or permanent vacancies occurred. ${ }^{56}$ The position began to improve after 1904, and subsequent Board Annual Reports indicate moderate numbers of re-admissions.

Patronage continued to be rife during this period. This is evident, firstly, from the issuance of special certificates for entry to the service - in the period 1901 to 1915, between 20 and 30 per cent of new entrants each year entered through special certificate rather than the usual competitive merit selection processes. ${ }^{57}$ Secondly, it is indicated by the continued excessive use of temporary employment. The $1901 \mathrm{Act}$ attempted to address the temporary employment problem by allowing temporary employees with more than five years service to become permanent public service officers without any examination, only requiring effluxion of time and a certificate of fitness from the minister or permanent head. ${ }^{58}$ This not only reduced the standard of entry for certain employees, but also provided extensive scope for patronage and the tenuring of unworthy candidates. However, the Premier protested that no ministers would make inappropriate appointments for the sake of giving jobs to friends. ${ }^{59}$ Nonetheless the excessive use of temporary employment continued to be a difficulty. Although no central statistics are available, by 1904 the Board was again urging departments to restrict temporary appointments to work of a genuinely temporary nature. ${ }^{60}$ As in the previous period, it is not possible to identify the basis for each retrenchment decision. However, this continued predisposition toward patronage in recruitment appears to have extended to dismissals, and retrenchments may again have been used for political as well as economic purposes.

The public service was affected by broader industrial and political developments following the election in 1915 of Queensland's first Labor government since the seven day tenure of the Dawson Labor ministry in $1899 .{ }^{61}$ In government, the expectation was that Labor would achieve the aims of the industrial movement through parliamentary means and via the machinery of arbitration. ${ }^{62}$ The public sector fared well, as the Ryan Labor government boosted the depressed wages of state employees and removed prohibitions on unionisation of police officers and other civil servants. ${ }^{63}$ Other public servants had already formed into a General Officers Association (GOA) and a Professional Officers Association (POA).${ }^{64}$ Public sector union membership grew significantly when the Industrial Arbitration Act, 1916 removed restrictions on government employees forming trade unions, and removed threats of dismissal or exclusion from promotion for union participation. Despite the legislative recognition of public sector unions, the Queensland Government 
nevertheless issued an Order-in-Council that removed those who earned $£ 300$ or more per annum from coverage of the Industrial Arbitration Act. ${ }^{65}$

The election of the Ryan Labor Government in 1915 led to some reduction in patronage, as evidenced by the reduced number of special entrance certificates issued. ${ }^{66}$ However it did not reduce temporary appointments, and public sector unions campaigned against the growth of temporary officers, who were 'largely ministerial appointments' and generally considered to be poor in quality, low in commitment, and doing work that existing officers could perform. Unions questioned the point of having rules on age and qualifications for admission if individuals could still enter by a side door. ${ }^{67}$ Both the GOA and POA urged the Ryan Government to review the public service arrangements, and create an independent Public Service Board, free from political and departmental influence. ${ }^{68}$ Public sector unions were instrumental in changes to employment in the 1920s.

\section{Public Service Act 1922}

The new Public Service Act Amendment Act 1920 provided for stronger merit and tenure processes, but gave the central personnel agency little power to implement these, and was soon revised. The Public Service Act $1922^{69}$ significantly reshaped public sector employment through enhancement of the career service conventions, and operated largely unchanged until the end of the 1980s. This Act continued a provision for redundancy, but through regulation rather than legislation. The Act provided that the Public Service Commissioner could make regulations for a range of purposes, one of which was the transfer, demotion or redundancy of surplus officers:

Where a greater number of officers is found to be employed in any department than ... necessary for the efficient working thereof, providing as circumstances require for the transfer of any officer who is in excess to another office of equal classification and salary; or if no such office is available, to an office of lower classification and salary or either of them; or for his retirement if he cannot be usefully and profitably employed elsewhere in the Service. [emphasis added] ${ }^{70}$

The subsequent 1923 Regulations ${ }^{71}$ carried almost identical wording to the Act, and remained materially unchanged until $1988 .{ }^{72}$ The 1922 Act continued the provision to re-appoint retrenched officers without examination or probation:

On the recommendation of the Commissioner, any person having at any time, either before or after the commencement of this Act, retired from any office in the Public Service shall, if not more than sixty years of age, be eligible for appointment by the Governor in Council to the Service without examination, and also, if so recommended, without probation. ${ }^{73}$

As in previous periods, there remained considerable scope for patronage. The 1922 Act continued the previous loophole that, if there were no qualified people available in the service, the Commissioner could recommend filling of a position without examination or probation..$^{74}$ The Act potentially restricted the inappropriate use of temporary employment through strict central controls, ${ }^{75}$ but subsequent assignments of power soon placed temporary employment decisions back in departmental hands, 
closer to political influence and without central scrutiny. Howatson ${ }^{76}$ has noted that temporary employment became a contentious issue at this time, and that politicians 'could make representations for the employment of a person'.

In the early 1920s, under the Theodore Labor Government, tenure was again affected by economic recession. In 1920, Queensland's unemployment rate of 16 per cent was more than double that of Australia as a whole. A revenue crisis led to a series of retrenchments that were bitterly opposed by unions (in departments such as public works and treasury). ${ }^{77}$ In the 12 months to June 1922, there were further rounds of wage reductions and retrenchments, with nearly 600 public servants retrenched, ${ }^{78}$ a figure equivalent to approximately 8 per cent of the total public service. workforce. However, union responses were tempered by fear of still further retrenchments. ${ }^{79}$ In November 1927, departmental heads were advised that the government was 'financially embarrassed', and that there was a need to further reduce expenditure..$^{80}$

The election of the conservative Moore Government in May 1929 coincided with the beginnings of an economic crisis of unparalleled severity. Dissatisfied with the Industrial Court decision to cut salaries by 6 per cent, the Government introduced its own Salaries Act 1930, ${ }^{81}$ cutting public service salaries by $10-15$ per cent in 1930, and a further 5 per cent in 1931. The Government defended these measures as being preferable to mass retrenchment. The Public Service Commissioner applied these measures as gently as possible, and found savings in contingency expenditure, which enabled a graduated scale and timing of salary reductions. ${ }^{82}$ The public sector workforce was further reduced in 1931, when the Moore Government closed all state enterprises, including butcher shops, the state produce agency, and the State Hotel Babinda. ${ }^{83}$ All public service unions campaigned heavily in the 1932 elections, and the press blamed public servants for contributing to the defeat of the Moore Government. $^{84}$

The post-war period was generally one of economic prosperity, and there were few changes to the public service employment framework. Indeed, there were staff shortages,, as unfavourable salaries made it difficult to attract and retain good candidates in the 1950s, and new salary and non-salary incentives had to be introduced. ${ }^{85}$ Prosperity meant that there were no extreme periods of recession, and therefore little need to use statutory powers to reduce government activities, retrench staff, ${ }^{86}$ or use temporary employment. The policy of the various governments from the 1940s until the 1980s was to guarantee that officers would not be retrenched, and reductions in staff numbers were achieved by natural attrition. ${ }^{87}$

The election of a new conservative Government in 1957 led to new regulations and processes. The Nicklin Country-Liberal government devolved further personnel processes to the departments, which in turn reduced central protections further and placed more recruitment decisions close to political influence. ${ }^{88}$ Temporary employment began to rise again, as the new government dispensed patronage to provide positions for its supporters. In 1963, Board concerns at the escalating rate of temporary employment led to a five-year drive toward permanent employment. While statistics are not available regarding the full extent of temporary employment in 1963, politicians subsequently boasted that by 1968 it had been significantly reduced to 264 temporary officers. ${ }^{89}$ 
Patronage continued to flourish after the Public Service Commissioner was replaced in 1968 by a less powerful Public Service Board. While there were no changes to the legislative provisions for redundancy or temporary employment, temporary employment rose due to the Board's lesser control over department decisions. In 1973 the Board again attempted to address the extent of temporary employment, by introducing another scheme allowing temporary officers to translate to permanent employment without facing full merit selection processes. ${ }^{90}$ This provided considerable opportunity for patronage and politicisation, and most likely weakened the standard of recruits.

\section{Deterioration of Tenure from the 1980s}

By the early 1980s, tenure was being weakened through the use of casual and contract employment, consultancies and the privatisation of public service functions, ${ }^{91}$ all of which affected the potential for political appointments and the quality of recruits. From 1987 on, industrial relations practices changed considerably throughout Australia, as wage-fixing incorporated productivity elements through Structural Efficiency and Award Restructuring Principles. Public sector unions were becoming more militant, discarding their traditional methods of lobbying and persuasion to achieve their goals. ${ }^{92}$ In Queensland, rising militancy was matched by an increasingly anti-union Government, which intervened in the industrial arena through extraarbitral legislation designed to reduce the power of unions and industrial tribunals, repress industrial action (such as in the SEQEB dispute), and bypass the system through voluntary employment agreements (VEAs). ${ }^{93}$

The Bjelke-Petersen government was also becoming frustrated with the perceived restrictiveness of public sector employment arrangements. It commissioned the Savage Review, ${ }^{94}$ which had far-reaching implications for all of the career service conventions, including tenure. The Savage Report criticised the inflexibility of the existing system as having no provisions for redundancy or early retirement, in light of longstanding career service concepts that granted affected officers wide options and salary maintenance for an indefinite period..$^{5}$ This was only partly true, as the 1922 Act had incorporated provisions for redundancy. Nonetheless, the career service conventions had generally been maintained - redundancy was ostensibly intended as a last resort where other options for retraining and redeployment were not possible, and with subsequent opportunities for the re-employment of retrenched officers.

Savage considered this long-term career focus inflexible and an impediment to new government directions (such as the reduction of the public service and the creation of new statutory authorities). He suggested that continued employment only applied to satisfactory service and the availability of work, and that a redundancy scheme did not alter this. His proposed scheme included options for retraining, redeployment, salary maintenance, termination and redundancy payments, and early retirement of officers over a certain age. ${ }^{96}$ The Labor Party opposed any legislative prerogative for retrenchments, which it considered could become the first option to overcome budgetary difficulties, and was generally not appropriate in a career service. ${ }^{97}$ The Government countered that Queensland's was the only Australian public service without such explicit legislated provisions..$^{98}$

In regard to staff retrenchment, the new Public Service Management and Employment Act 1988 provided as follows: 
28. Retrenchment. Where the Governor in Council is satisfied that -

(a) the services of an officer of the public service can no longer be gainfully utilized in the office held by the officer because the office has become redundant;

(b) it is not practicable to retrain or redeploy the officer; and

(c) the redundancy arrangements approved by the Governor in Council have been complied with in relation to the officer,

he may terminate the services of the officer by way of retrenchment in accordance with those redundancy arrangements. ${ }^{99}$

This provision provided more flexibility, relaxing the criteria from 'cannot be usefully and profitably employed elsewhere' to 'it is not practicable to retrain or redeploy the officer'. However, contrary to Labor's suggestions, these retrenchment provisions were not all that dissimilar to those that had applied previously. No information has been located regarding the use of this provision, due in part to the short time interval before the subsequent change of government in 1989, and due partly to the decentralisation of HRM activities and discontinuation of centralised personnel monitoring in this period. The 1988 Act continued the previous opportunities for patronage in recruitment, but also went further by providing that a department could engage a temporary employee on any terms agreed with the chief executive. ${ }^{100}$ However, as with the redundancy provisions, the change of government in 1989 limited the extent to which this provision could be abused.

\section{The Goss Government Reforms}

The Goss Labor Government was elected in 1989 partly on a platform of extensive reform and restructuring of the public service. ${ }^{101}$ In the first term of this Government many of the career service conventions were strengthened through a new employment framework, which included more stringent and appropriate merit selection processes, extended appeal processes, greater central control over temporary employment, and restored tenure for senior officers. ${ }^{102}$ This framework re-focused personnel decisions on merit and significantly reduced opportunities for patronage. However, the opening of new vacancies to national competition was a novel element, a significant departure from the Queensland tradition of a 'closed shop'. ${ }^{103}$ There were extensive accusations about the influx of 'Mexicans' and 'Labor mates', 104 although Queensland applicants were appointed to 84 per cent of vacant senior positions. ${ }^{105}$ The Opposition failed to meet the Premier's invitation to identify any appointees who did not meet merit criteria for the position, ${ }^{106}$ but there was insufficient monitoring to gauge the extent to which individual decisions were based on merit.

The existing redundancy policies were found inadequate to support this restructuring, and significant changes were made to broaden the use of redundancy and retrenchment. In 1991 departmental heads were given greater flexibility to offer early retirement during major organisational change, and employees were given more options to sever their career service employment. The retrenchment provision was extended to include situations when the duties were performed by another officer, and when an officer elected not to participate in redeployment or retraining: 
28. Retrenchment. Where the Governor is satisfied that -

(a) an officer no longer holds an office, or the office held by an officer is surplus to the requirements of the departments concerned because -

(i) the duties of the office are no longer required; or

(ii) the duties of the office are being performed by the holder of another office; and

(b) it is not practicable to retrain or redeploy the officer or the officer notifies the chief executive of the department concerned, in writing, that the officer elects not to be retrained or redeployed; and

(c) redundancy arrangements under the regulations or the standards, or approved by the Governor in Council, have been complied with in relation to the officer,

he may terminate the services of the officer by way of retrenchment in accordance with those redundancy arrangements. ${ }^{107}$ [emphasis added]

These changes facilitated increased redundancy during the first term of the Goss government. ${ }^{108}$

The redundancy provisions prevailing before 1988 only applied to surplus positions, and appear to have been utilised in times of economic crisis, with subsequent opportunity for re-employment as economic circumstances improved. By contrast, more recent legislative changes have generally been introduced in response to new circumstances and requirements, such as the increasing transfer of services to statutory authorities under the National Party, or organisational restructuring under the Goss Government. The longstanding convention of career service employment also seemed to have waned, as governments removed the earlier provision for reemployment when circumstances improved.

\section{Conclusion}

Prior to the advent of the career service model, there was little employment security, as each new government sought to provide favours to its own supporters. The Northcote-Trevelyan recommendation that officers be permanent and independent recognised the political nature of public service work and represented a major departure from private sector employment relations. Employment security enabled a professional and impartial public service to provide frank and fearless advice, without fear of dismissal, to governments of any political persuasion. Employment structures reflected these needs.

This study of public service employment practices in Queensland suggests several conclusions regarding the nature of public sector employment security. First, it has challenged the perception that the recent spate of redundancies is somehow novel. It confirms McCarry's argument that tenure was never a legislated entitlement and that, on the contrary, legislation in Queensland has always provided for retrenchment. These redundancy provisions have been used throughout Queensland's history, generally in times of economic crisis, when public servants generally had no more security than their private sector counterparts. Economic prosperity after World War II resulted in these provisions being little used. Recent legislative changes have not introduced redundancy provisions; rather these initiatives have made such provisions easier to access in a wider range of circumstances. 
Second, the findings indicate that Littler's argument regarding the changing nature of redundancy applies equally in the public sector. In earlier times, redundancy was related to surplus positions, and appeared to be used during economic downturns, with scope for re-employment of retrenched officers in the future. However since 1988, redundancy provisions were modified several times to meet new requirements regarding changing organisational structures or organisational improvement.

There does not appear to be any strong correlation between tenure and the political party in power, although some general observations can be made. Peak periods of redundancy prior to the 1980s appear to have been related to cyclical economic downturns, and occurred under both Labor and conservative governments. The relaxation of redundancy provisions in 1988 occurred under a conservative government, but similar trends were occurring in all other Australian states, as well as at the federal level, regardless of the political party in power. There is perhaps greater correlation between temporary employment and political party. Conservative governments have tended to favour devolution of personnel decisions to departments, which increased the scope for patronage. Labor governments have initiated the most far-reaching reforms to public service employment (in 1922 and 1989); reforms which have sought to restore merit and tenure processes.

What does this mean for the convention of tenure, which was part of a broader employment framework intended to make it difficult to enter public service employment other than on merit, and difficult to be removed other than on merit? Put simply, the increasing flexibility and accessibility of redundancy provisions is not consistent with this traditional intention. The rationale for individual recruitment and redundancy decisions is impossible to fathom. However, this paper has demonstrated the ongoing preparedness of governments, particularly those of a conservative persuasion, to exercise patronage in recruitment, both through temporary employment and special certificates for entry, and this predisposition in recruitment must raise suspicion that redundancy may have been used in a similar way.

\section{Endnotes}

* This article has been peer-reviewed for Labour History by two anonymous referees.

1. M.A. Stanton, The Merit Principle: Its History and Future, Public Service Board, AGPS, Canberra, 1978 , p. 2.

2. E.W. Cohen, The Growth of the British Civil Service 1780-1939, Frank Cass and Co, London, 1965, pp. 38-41; E.N. Gladden, 'Charles Trevelyan and Civil Service Reform'; Public Administration (Australia), vol. XIII, September 1954, p. 144; M. Jackson, 'Keynote Address' at National Conference on the Future of Merit Protection Systems in Public Sector Employment, PSMC and CAPSM, Griffith University, 1993, p. 2.

3. S. Northcote and C. Trevelyan, Report on the Organisation of the Permanent Civil Service, 23 November 1853, (hereafter 1853 Report) submitted to both Houses of Parliament by Command of Her Majesty in February 1854 (Paper 1713 in the British Parliamentary Papers)

4. Northcote and Trevelyan, 1853 Report, p. 1.

5. G. Caiden, Career Service, Melbourne University Press, Melbourne, 1965; Northcote and Trevelyan, 1853 Report.

6. M. Gardner, Human Resource Management and Industrial Relations in the Public Sector, MacMillan, South Melbourne, 1993, p. 138; B. McCallum, The Public Service Manager, Longman Cheshire, Melbourne, 1984; G. McCarry, Aspects of Public Sector Employment Law, Law Book Company, 1988; G. McCarry, 'The Demise of Tenure in Public Sector Employment' in R. McCallum, G. McCarry and P. Ronfeldt, Employment Security, Federation Press, Sydney, 1994.

7. Australian Centre for Industrial Relations Research and Training (ACIRRT), Australia at Work: Just Managing?, Prentice Hall, Sydney, 1999, p. 126.

8. ACIRRT, Australia at Work, p. 147. 
9. Ibid., pp. 147-8.

10. C.R. Littler, R. Dunford, T. Bramble and A. Hede, 'The Dynamics of Downsizing in Australia and New Zealand', Asia Pacific Journal of Human Resources, vol. 35, no. 1, 1997, p. 66.

11. Termination of Employment Convention 1982, International Labor Organisation (ILO) Convention No. 158

12. B. Creighton and A. Stewart, Labour Law: An Introduction, Federation Press, Leichardt NSW, 2000, p. 291.

13. C.R.Littler (1997) in ACIRRT, Australia at Work, p.148.

14. Ibid, pp. 147-8.

15. Creighton and Stewart, Labour Law, p. 331.

16. McCarry, 'The Demise of Tenure', p. 138.

17. Ibid., pp. 144, 149.

18. Civil Service Act 1863.

19. Civil Service Act 1863, s. 8.

20. Queensland Parliamentary Debates, 18 April 1866, pp. 56-60.

21. Ibid., p. 56.

22. Queensland Parliamentary Debates, 18 April 1866, pp. 56-60; 15 June 1869, pp. 333-339.

23. Caiden, Career Service, p. 38.

24. Civil Service Acts Repeal Act 1869.

25. C.A. Bernays, Queensland Politics During 60 Years 1859-1919, Government Printer, Brisbane, 1919, p. 471; D.R. Hall 'Strike Law in Queensland' in D.J. Murphy (ed.), The Big Strikes: Queensland 18891965, University of Queensland Press, St Lucia Qld, 1983, p. 15.

26. D.J. Murphy, 'Trade unions' in Murphy (ed.), The Big Strikes, p. 36.

27. Gillian Whitehouse and Kenneth Wiltshire, The History of the Queensland Professional Officers Association, Royal Australian Institute of Public Administration (Queensland Division) in association with the Queensland Professional Officers Association, Brisbane, 1987, pp. 10-12.

28. Caiden, Career Service, p. 48; Whitehouse and Wiltshire, The History of the Queensland Professional Officers Association.

29. Second Progress Report of the Royal Commission into the General Working of the Civil Service and the Mode of Keeping the Public Accounts of the Colony, Minutes of Evidence, Queensland Legislative Assembly, 1889, p. 24.

30. Civil Service Act 1889.

31. Public Service Act 1896.

32. Civil Service Act 1889, s. 33.

33. Civil Service Act 1889, s. 71.

34. D.W. Fraser, 'The Public Service of Queensland, 1958,' in D.W. Fraser, The Public Service of Queensland 1859-1959: Selected Papers, Australian Institute of Public Administration, Queensland Regional Group Monograph 4, 1981, p. 3; First Report of the Civil Service Board (CSB) of Queensland for the Year 1890, p. 12.

35. Ministerial Letterbooks, Queensland State Archives, RSI 13644 B/1726, Folio 40 of 1901 and Folio 90 of 1903.

36. Civil Service Board (Queensland) Annual Reports 1891 - 1895, Queensland Government Printer, (accessed through the Queensland Government Department of Premier and Cabinet library).

37. Civil Service Board, 1891, p. 6; Civil Service Board, 1893, p. 6.

38. Register of Officers Eligible for Re-Employment, Queensland State Archives, RSI 13691, from 1901.

39. Special Retrenchment Act 1893.

40. $\quad$ Bernays, Queensland Politics During 60 Years, pp. 134-136.

41. Caiden, Career Service, p. 42.

42. Report of the Public Service Board (PSB) for the year 1899 (Queensland), Queensland Government Printer, p. 6.

43. J. Scott, R. Laurie, B. Stevens and P. Weller, The Engine Room of Government: The Queensland Premier's Department 1859-2001, University of Queensland Press, St Lucia, 2001, p. 55.

44. Scott et al, The Engine Room of Government, p. 55.

45. Caiden, Career Service, p. 48; Public Service Board, 1899, p. 3.

46. Queensland Parliamentary Debates, 22 October 1896 p. 1263.

47. Public Service Board 1899, p. 3.

48. Civil Service Board (Queensland) Annual Reports, 1890-1895; Public Service Board (Queensland) Annual Reports, 1896-1900, Queensland Government Printer.

49. Public Service Act Amendment Act 1901, ss. 4-5.

50. Departments of Posts and Telegraphs, Customs and Excise, and Defence. Report of the PSB for the year 1901 (Queensland), p. 2.

51. Queensland Parliamentary Debates, 23 October 1901, p. 1425.

52. Member of Parliament Barlow, in Fraser (1958) The Public Service of Queensland, p. 5.

53. Public Service Act Amendment Act 1901; Public Service Acts Amendment Act 1920.

54. Special Retrenchment Act 1902.

55. Report of the Public Service Board (PSB) for the year 1902 (Queensland); Report of the Public Service Board (PSB) for the year 1903 (Queensland); Report of the Public Service Board (PSB) for the year 1904 (Queensland); Report of the Public Service Board (PSB) for the year 1905 (Queensland), Queensland Government Printer. 
56. PSB, 1904, p. 4.

57. Civil Service Board and Public Service Board Annual Reports 1890-1915.

58. $\quad$ Public Service Act Amendment Act 1901 s. 6.

59. Queensland Parliamentary Debates, 24 October 1901, pp. 1464-1466.

60. PSB, 1904, p. 4.

61. Colin Hughes, The Government of Queensland, University of Queensland Press, St Lucia, 1980, pp. 83-4.

62. Bernays, Queensland Politics During 60 Years, pp. 487-488; R. Fitzgerald and H. Thornton, Labor in Queensland from 1880s to 1988, University of Queensland Press, St Lucia, 1989, pp. 25-26.

63. Fitzgerald and Thornton, Labor in Queensland, p. 27.

64. Whitehouse and Wiltshire, The History of the Queensland Professional Officers Association, p. 20.

65. Report of the Public Service Board for the year 1917 and 1918 (Queensland), p. 1, Queensland Government Printer.

66. Report of the Public Service Board for the year 1916, PSB 1917 and 1918, Queensland Government Printer.

67. General Officers Association (GOA), The State Service, members journal, Sept 1919; Oct 1920; Sept 1921.

68. GOA, The State Service, May 1917, p. 1; April 1918, p. 1; Professional Officers' Association The Echo, members newsletter, January 1918, pp. 2-4.

69. Public Service Act 1922

70. Public Service Act 1922, s. 51(1)(iv).

71. Public Service Act 1922, 1923 Regulations, r. 108.

72. R.J. Howatson, Queensland Public Service: A Short History of Legislation from 1922 to 1987, Royal Australian Institute of Public Administration (Queensland Division) Monograph No 11, 1988, p. 18.

73. Public Service Act 1922, s. 18(3)(iii).

74. Public Service Act 1922, s. 18(3)(iv)

75. Public Service Act 1922, s. 18(3)(v).

76. Howatson, Queensland Public Service, p. 9

77. Whitehouse and Wiltshire, The History of the Queensland Professional Officers Association, pp. 51-52.

78. Scott et al, The Engine Room of Government, p. 88.

79. Whitehouse and Wiltshire, The History of the Queensland Professional Officers Association, pp. 51-52.

80. $8^{\text {th }}$ Annual Report of the Public Service Commissioner for the year ended 30 June 1928 (Q1d), p. 10. 81. Salaries Act 1930.

82. D. Fraser, 'J.D. Story: His contribution to Public Service Administration', in D. Fraser, M. Thomis, C. Clark and D. Conroy, Administrative History in Queensland, Royal Australian Institute of Public Administration, Queensland Division, Monograph No 8, November 1986, p. 8; C. Lack, Three Decades of Queensland Political History 1929-1960, Government Printer, Brisbane, 1961, pp. 64, 78, 99, 106,$109 ; 11^{\text {th }}$ Annual Report of the Public Service Commissioner for the year ended 30 June 1931 (Qld).

83. Lack, Three Decades of Queensland Political History, p. 119.

84. Whitehouse and Wiltshire, The History of the Queensland Professional Officers Association, p. 84.

85. Lack, Three Decades of Queensland Political History, p. 761; $37^{\text {th }}$ Annual Report of the Public Service Commissioner (PSC) (1958), pp. 12-13; 39 th Annual Report of the Public Service Commissioner (1959), p. 31.

86. McCarry, 'The Demise of Tenure', p. 150.

87. Howatson, A Short History of Legislation, p. 18.

88. PSC 1958, p. 2.

89. Queensland Parliamentary Debates, 11 December 1968: 2313.

90. Public Service Board Annual Report 1972-1973 (Queensland), p. 3.

91. Queensland State Services Union (QSSU), The State Service, June 1984, p. 11; July 1984, p. 25; August 1984 p. 12; March 1986, p. 4.

92. M. Simms, Militant Public Servants: Politicisation and Selected Public Service Unions, MacMillan, South Melbourne, 1987.

93. J. Fleming, New Governments in Queensland: Industrial Relations, 1957-1961, 1989-1990, PhD Thesis, Griffith University, 1998, pp. 133-134; M.L. Goodwin, Voluntary Employment Agreements, Honours Dissertation, Griffith University, 1989, pp. 6-7; QSSU, The State Service, various editions as detailed above.

94. E. Savage, Report on the Review of the Public Sector in Queensland, Queensland Government Printer, 1987.

95. Savage, Report on the Review of the Public Sector in Queensland, pp.57-58.

96. Ibid.

97. Queensland Parliamentary Debates, 20 April 1988, p. 6237.

98. Queensland Parliamentary Debates, 21 April 1988, p. 6300.

99. Public Service Management and Employment Act 1988, s.28.

100. Public Service Management and Employment Act 1988, s.34

101. W. Goss, Making Government Work: Public Sector Reform Under a Goss Government, Policy 
Paper prepared by the Transition to Government Committee of the State Parliamentary Labor Party, August 1989.

102. Public Sector Management Commission Standard for Recruitment and Selection (1991 and 1993), Public Sector Legislation Amendment Act 1991.

103. Public Sector Management Commission (1990) A Green Paper on Senior Executive Service Queensland, pp. 2-3.

104. G. Davis, A Government of Routines, Macmillan, South Melbourne, 1995, p. 114; Queensland Parliamentary Debates, 29 May 1991, pp. 8085, 8087, 8088.

105. Davis, A Government of Routines, p. 114.

106. W. Goss 'Ministerial Statement', October 1991, cited in G. Davis (ed.), Public Sector Reform Under the First Goss Government, Royal Institute of Public Administration Australia and Centre for Australian Public Sector Management, Griffith University, Brisbane, 1993, pp. 199-200.

107. Public Service Management and Employment Act 1988 (s.28), varied 1991 and 1994.

108. G. Davis, 'Introduction', in Davis (ed.), Public Sector Reform Under the First Goss Government, p. iii. 